\title{
MANGROVE IN THE COASTAL ZONE OF LAMPUNG BAY PROVINCE OF LAMPUNG: A PRELIMINARY STUDY
}

\author{
Pramudji \\ Research Center for Oceanography, Indonesian Institute of Sciences \\ J1. Pasir Putih I, Ancol Timur, Jakarta 11048, Indonesia \\ E-mail:pram3588@yahoo.com.
}

\begin{abstract}
Study on mangrove forest in the coastal zone of Lampung Bay, Province of Lampung was carried out on March $12-30,2007$. The data was collected from 8 stations, (Pidada Bay, Limbungan, Puhawang Kecil Island, Kalangan, Klagian Island, Kapuran, Ringgung, and Hurun Bay) based on the transect method. The result showed that the mangrove in the coastal zone of Lampung Bay was dominated by Rhizophora apiculata. The floristic composition of mangrove in this area consisted of 31 species. Recently, the extent of mangrove in the coastal zone of Lampung Bay was decreasing due to conversion of mangrove into human settlement, fishpond, road, and uncontrolled mangrove exploitation. This situation leads to the depletion of the living organisms which inhabit this area.
\end{abstract}

\section{INTRODUCTION}

Mangrove ecosystem occurs world wide on the tropical and sub-tropical coastlines (McNae, 1968; Chapman, 1976; and Tomlison, 1986). Mangrove occupies the area of the coastal zone between the mean sea level and the extreme high water of spring tides. They thrive best in sheltered tidal flats, bays, and estuaries. Mangrove forest is also known as beach forest, tidal or brackish water forest.

Mangrove is among the most productive ecosystems and offers a wide range of resources and services including shoreline habitat, nursery ground for many kinds of aquatic and terrestrial organisms (Snedaker and Getter, 1985; Bosire et al., 2003). Bosire et al. (2005) mentioned that this high productivity is often attributed to high litter degradation rates and efficient recycling of nutrients, which is supplied by autochthonous nature and anthropogenic sources. Mangrove forest also has essential roles in sustaining estuarine and near shore ecosystems, therefore it plays a key role in maintaining high fishery yield, stabilizing and acting as barriers on marginal beach. Economically, mangrove forest has played an important role for the tropical people for thousand of years and constitute a reservoir and refuge for many kinds of specific plants and animals (Hamilton and Snedaker, 1984).

In recent years, the over-exploitation of coastal areas due to various anthropogenic activities has accelerated the degradation of mangrove. The destruction of mangrove due to the increasing needs of fire wood, housing, harbor, and agricultural land in Indonesia has caused serious problem of erosion. Notohadipoero and Siradz (1978) and Syukur (1984) found out that landslide and coastal erosion happened as a consequence of the conversion of mangrove forest for agriculture purposes. Pramudji (2000), Pramudji and Hermanto (1987), Dutrieux (1991), and Soemodihardjo et al. (1992) noticed that the same condition was also found in some areas in Indonesia i.e. along cost of the northern Java, Cilacap, West Lombok, Mahakam Delta (East Kalimantan), Saleh Bay (Sumbawa Island), Waisiley and Sidangoli (Halmahera Island).

Large scale of the area of mangrove in Indonesia has been converted to brackish water fishpond. In 1980, the conversion of the area was 155.081 hectares, and most of them were distributed mainly in Java, Sumatra, and Sulawesi. In 1990, the brackish water fishpond in Indonesia covered an area of 285.500 hectares, but more than 173.088 hectares of mangrove land was 
already converted into fishpond. Pramudji and Hermanto (1987) mentioned that the areas of mangrove along West Lombok have been destroyed and transformed into fishpond, salt pond, and mining activities.

This paper assesses the present condition of the mangrove resources in the coastal area of Lampung Bay. The zonation scheme and management prospect are also presented.

\section{MATERIALS AND METHOD}

The present study was conducted at Lampung Bay, Province of Lampung. A total of 8 stations were located along the coast of Lampung Bay, i.e. Pidada Bay $\left(05^{\circ} 45^{\prime} 08.5^{\prime} \mathrm{S}-105^{\circ} 09^{\prime} 21.4^{\prime \prime}\right.$ E), Limbungan $\left(05^{\circ} 43^{\prime} 19.6^{\prime \prime} \mathrm{S}-105^{\circ} 12^{\prime} 10.0^{\prime \prime}\right.$ E), Puhawan Kecil Island (05 40' $25.0^{\prime \prime} \mathrm{S}-105^{\circ}$ 14' 27.1" E), Kalangan ( $05^{\circ} 39^{\prime} 25.1^{\prime \prime} \mathrm{S}-105^{\circ}$ $\left.11^{\prime} 58.8^{\prime \prime} \mathrm{E}\right)$, Klagian Island ( $05^{\circ} 38^{\prime} 15.6^{\prime \prime} \mathrm{S}-$ $\left.105^{\circ} 13^{\prime} 13.3^{\prime \prime} \mathrm{E}\right)$, Kapura (05⒊ $35^{\prime} 13.3^{\prime \prime} \mathrm{S}-105^{\circ}$ 14' 28.7” E), Ringgung (053' $36.2^{\prime \prime} \mathrm{S}-105^{\circ}$ $\left.15^{\prime} 08.6^{\prime \prime} \mathrm{E}\right)$, and Hurun Bay (05 31' $14^{\prime \prime} \mathrm{S}-$ $105^{\circ} 15^{\prime} 06.6$ " E).

The transect lines perpendicular to the shore line were established across the mangrove forest from the shore to the sea. Mangrove vegetation data was collected from the plots of $10 \mathrm{~m} \times 10 \mathrm{~m}$ along the transect line. In each plot, all trees with dbh (diameter at breast height $\mathrm{e} \cdot 10 \mathrm{~cm}$ ) were measured (diameter and height), and identified to species. The number of sapling $(2<\mathrm{dbh}<10 \mathrm{~cm})$ of each species was recorded within each $5 \mathrm{~m} \times 5$ $\mathrm{m}$ quadrate, and the numbers of seedling (stem diameter, just above the tip of hypocotyls $\mathrm{e} \cdot 2 \mathrm{~cm}$ ) within each $1 \mathrm{~m} \mathrm{x} 1 \mathrm{~m}$ quadrate. The various vegetation data measurements were determined according to Cox (1967), English et al. (1994), and Snedaker and Snedaker (1984).

\section{RESULT AND DISCUSSION}

The mangrove forests of Lampung Bay occupy the area of the coastal zone between the mean sea-level and the extreme high water of spring tides. They thrived in sheltered tidal flats, bays, and estuaries. This ecosystem predominantly comprised of trees and herb, which were unrelated taxonomically but have similar physiological characteristics and structural adaptations.

A total of 31 species of mangrove were observed in the area and the species of
Rhizophora apiculata and Sonneratia alba represented the most abundant and covered the seaward area. Behind this zone, the area was occupied by the community of Rhizophora $x$ lamarckii, Rhizophora mucronata, Bruguiera gymnorrhiza, Bruguiera cylindrica, Ceriops tagal, and followed by Xylocarpus granatum, Excoecaria agallocha, Heritiera littoralis, Pongamia pinnata, and Pemphis acidula at the landward area. At several stations i.e. Pidada Bay, Kalangan, and Kapuran, the dominant species at the seaward area was Rhizophora $x$ lamarkii.

Table 1 shows the mangrove species reported to be found around Lampung Bay. The true mangrove components were most commonly represented by Rhizophora apiculata, Rhizophora mucronata, Rhizophora $x$ lamarckii, Bruguiera cylindrica, Sonneratia alba, Xylocarpus granatum, and Avicennia marina. At rather dry locations, Heritiera littoralis, Pemphis acidula, Pongamia pinnata, and Excoecaria agallocha were found. The dominant undergrowths included Derris trifoliata, Sesuvium portulacastrum, and Ipomea pescaprae.

The variation in species composition from place to place was quite distinctive. At the accretion location, pure stands of Sonneratia alba or Rhizophora mucronata or both usually occurred. The non-accreted area was normally populated by mixed mangrove communities of several species. The most complex community contained up to 16 mangrove species. It was observed from Kalangan, Kapuran, Ringgung, and Hurun Bay that Rhizophora apiculata and Rhizophora lamarckii usually dominated the community. At the transitional areas, the plant community included some salt-tolerant dryland vegetation such as Barringtonia racemosa, Calophyllum inophyllum, Cerbera manghas, Dolichandron spathacea, Hibiscus tiliaceus, Pandanus tectorius, and Thespesia populnea.

Mangrove forest of Lampung Bay was still intact. In general, mangrove area has experienced pressure of human activity, and most of which are negative. The decrease of the mangrove area in Lampung Bay was due to conversion, particularly for fishpond. Mangrove degradation was also due to illegal exploitation for fuel-wood and housing materials.

The condition of mangrove in Lampung Bay was a slightly disturbed category to moderately 
Table 1. Species of mangrove and associated plants of the coastal zone of Lampung Bay. Nomenclature follows Steenis (1978), Kitamura et al. (1997), Noor et al. (1999), Primavera et al. (2004).

\begin{tabular}{|c|c|c|c|c|c|c|c|c|c|}
\hline \multirow{2}{*}{ No } & \multirow{2}{*}{ Species } & \multicolumn{8}{|c|}{ Location } \\
\hline & & 1 & 2 & 3 & 4 & 5 & 6 & 7 & 8 \\
\hline 1 & Acanthus ilicifolius & + & + & + & + & + & + & + & + \\
\hline 2 & Acrostichum aureum & + & + & + & + & + & + & + & + \\
\hline 3 & A. speciosum & - & - & - & + & - & - & - & + \\
\hline 4 & Avicennia marina & + & - & - & + & - & + & - & + \\
\hline 5 & Baringtonia asiatica & - & + & - & + & - & + & - & + \\
\hline 6 & Bruguiera cylindrica & - & - & - & + & + & + & + & + \\
\hline 7 & B. gymnorrhiza & + & + & - & + & + & + & + & + \\
\hline 8 & Calophyllum inophyllum & - & - & - & - & - & + & - & + \\
\hline 9 & Ceriops tagal & - & + & - & + & - & + & + & + \\
\hline 10 & Derris trifolia & - & - & - & - & + & + & + & + \\
\hline 11 & Excoecaria agallocha & - & + & - & + & + & + & + & + \\
\hline 12 & Heritiera littoralis & - & + & - & - & - & - & - & - \\
\hline 13 & Hibiscus tiliaceus & - & + & + & + & + & + & + & + \\
\hline 14 & Ipomoea pes-caprae & - & + & - & + & + & + & + & + \\
\hline 15 & Melastoma candidum & - & + & - & + & - & - & + & + \\
\hline 16 & Nypa fruticans & - & - & - & - & - & + & $\cdot$ & + \\
\hline 17 & Pandanus tectorius & - & - & - & - & + & - & - & - \\
\hline 18 & Phemphis acidula & - & - & - & + & - & + & + & + \\
\hline 19 & Pongamia pinnata & - & $\cdot$ & - & + & + & + & + & + \\
\hline 20 & Rhizophora apiculata & + & + & + & + & + & + & + & + \\
\hline 21 & R. lamarckii & + & + & + & + & + & + & + & - \\
\hline 22 & R. mucronata & + & + & + & + & + & + & + & + \\
\hline 23 & R. stylosa & + & - & + & - & + & - & + & + \\
\hline 24 & Scaevola taccada & - & - & - & - & + & + & - & + \\
\hline 25 & Scyphiphora hydrophyllacea & - & $\cdot$ & - & - & + & - & + & + \\
\hline 26 & Sesuvium portulacastrum & - & - & - & $\cdot$ & - & + & + & + \\
\hline 27 & Sonneratia alba & + & + & + & + & - & + & + & + \\
\hline 28 & Terminalia catappa & - & - & - & + & + & + & - & + \\
\hline 29 & Thespesia populnea & - & + & + & + & + & + & + & - \\
\hline 30 & Xylocarpus granatum & - & + & - & + & + & + & + & + \\
\hline 31 & $X$. mekongensis & - & - & - & - & + & - & - & + \\
\hline
\end{tabular}

disturbed category. Some areas were heavily disturbed categories i.e. Pidada Bay, Puhawang Island, and Ringgung.

The condition of mangrove vegetation in coastal zone of Lampung Bay depended on its locations, number of species, and density (tree and sapling). In general, the density of the tree was about $100-428$ trees $\mathrm{ha}^{-1}$, the sapling was 1,313 3,800 saplings $\mathrm{ha}^{-1}$, and the seedling was $12,857-$ 37,142 seedlings ha-1 (Table 2 ).

Of the study conducted, in general Rhizophora apiculata had the highest value of density both for tree and sapling groups, except at Pidada Bay. Another species which had the high density value was Sonneratia alba. According to Yuniarto et al. (2005), the high value of density shows that the species has a good regeneration.
The good regeneration possibly make the habitat better for the future, and in return this condition will contribute to the number of trees which grow and develop.

Based on the study, the highest density value was that of the seedling group, followed by sapling group, and the lowest was the tree group. The high difference of the density values between tree and seedling group was influenced by some factors such as the low density value of tree group caused the open area, consequently the sunshine could reach the forest floor. This condition would trigger the growth of the seed so the density of the seedling would increase.

The frequency level of a species can be seen from the value of relative frequency of the species found at an area. In general, Rhizophora 
Table 2. Density of trees, sapling, and seedling per hectare ( $1=$ Pidada Bay, $2=$ Limbungan, $3=$ Puhawang, 4=Kalangan, $5=$ Klagian Island, $6=$ Kapuran, $7=$ Ringgung, and 8=Hurun Bay).

\begin{tabular}{|c|c|c|c|c|c|c|c|c|}
\hline \multirow{2}{*}{ Species } & \multicolumn{8}{|c|}{ Transect (tree categoy) } \\
\hline & 1 & 2 & 3 & 4 & 5 & 6 & 7 & 8 \\
\hline Rhizophora apiculata & 40 & 214 & 100 & 166 & 228 & 150 & 92 & 212 \\
\hline Rhizphora $x$ lamarckii & 70 & - & - & 83 & 14 & 75 & - & - \\
\hline Rhizophora mucronata & - & - & - & - & 143 & 63 & - & - \\
\hline Bruguiera gymnorrhiza & - & $\cdot$ & - & - & 43 & - & - & - \\
\hline Avicennia marina & 60 & - & - & - & - & - & - & - \\
\hline Sonneratia alba & 130 & 142 & 66 & - & - & - & 8 & 25 \\
\hline Ceriops tagal & - & - & - & 16 & - & - & - & - \\
\hline Excoecaria agallocha & - & - & - & 50 & - & - & - & - \\
\hline \multicolumn{9}{|c|}{ Sapling category } \\
\hline Rhizophora apiculata & 740 & 1142 & 733 & 600 & 800 & 150 & 3733 & 2600 \\
\hline Rhizphora x lamarckii & 160 & - & - & 200 & - & 250 & - & - \\
\hline Rhizophora mucronata & 60 & - & 333 & 133 & 743 & 450 & - & - \\
\hline Bruguiera gymnorrhiza & - & - & - & - & 144 & 100 & - & - \\
\hline Bruguiera cylindrica & - & - & - & - & - & 150 & - & - \\
\hline Avicennia marina & 260 & - & - & - & - & - & - & - \\
\hline Sonneratia alba & 60 & 171 & 600 & - & - & - & 67 & 50 \\
\hline Ceriops tagal & - & - & - & 333 & - & 100 & - & - \\
\hline \multicolumn{9}{|c|}{ Seedling category } \\
\hline Rhizophora apiculata & 20000 & 12857 & 30000 & 8333 & 31428 & 13750 & 34166 & 25000 \\
\hline Rhizphora x lamarckii & 6000 & - & - & - & - & 10000 & - & - \\
\hline Rhizophora mucronata & - & - & 833 & 1666 & 5714 & 3750 & - & - \\
\hline Avicennia marina & 10000 & - & - & - & - & - & - & - \\
\hline Sonneratia alba & - & - & - & - & - & - & - & 3750 \\
\hline Ceriops tagal & - & - & - & 13333 & - & - & - & $\cdot$ \\
\hline
\end{tabular}

Table 3. Species composition (trees) and community indices (\%) of the mangrove community of coastal zone of Lampung Bay.

\begin{tabular}{|c|c|c|c|c|c|c|c|c|}
\hline \multirow{2}{*}{ Species } & \multicolumn{8}{|c|}{ Transect } \\
\hline & 1 & 2 & 3 & 4 & 5 & 6 & 7 & 8 \\
\hline \multicolumn{9}{|c|}{ Relative frequency (\%) } \\
\hline Rhizophora apiculata & 16.00 & 66.67 & 50.00 & 50 & 55.56 & 37.50 & 83.33 & 87.50 \\
\hline Rhizphora $x$ lamarckii & 16.00 & - & - & 16.67 & 11.11 & 37.50 & - & - \\
\hline Rhizophora mucronata & - & - & - & - & 22.22 & 25.00 & - & - \\
\hline Bruguiera gymnorrhiza & - & - & - & - & 11.11 & - & - & - \\
\hline Avicennia marina & 24.00 & - & - & - & - & - & - & - \\
\hline Sonneratia alba & 44.00 & 33.33 & 50.00 & - & - & - & 16.67 & 12.50 \\
\hline Ceriops tagal & - & - & - & 16.67 & - & - & - & - \\
\hline Excoecaria agallocha & - & - & - & 16.67 & - & - & - & - \\
\hline \multicolumn{9}{|c|}{ Relative dominace (\%) } \\
\hline Rhizophora apiculata & 8.98 & 67.69 & 41.50 & 47.62 & 78.64 & 48.97 & 85.81 & 65.98 \\
\hline Rhizphora x lamarckii & 26.17 & - & - & 14.00 & 1.86 & 27.24 & - & - \\
\hline Rhizophora mucronata & - & - & - & - & 14.28 & 23.79 & - & - \\
\hline Bruguiera gymnorrhiza & - & - & - & - & 5.22 & - & - & - \\
\hline Avicennia marina & 52.52 & - & - & - & - & - & - & - \\
\hline Sonneratia alba & & 32.31 & 78.02 & - & - & $\cdot$ & 14.19 & 34.02 \\
\hline Ceriops tagal & - & - & - & 34.05 & - & - & - & - \\
\hline Excoecaria agallocha & - & - & - & 25.41 & - & - & - & - \\
\hline
\end{tabular}


Table 4. Species composition (saplings) and community indices (\%) of the mangrove community of the coastal zone of Lampung Bay

\begin{tabular}{|c|c|c|c|c|c|c|c|c|}
\hline \multirow{2}{*}{ Species } & \multicolumn{8}{|c|}{ Transect } \\
\hline & 1 & 2 & 3 & 4 & 5 & 6 & 7 & 8 \\
\hline \multicolumn{9}{|c|}{ Relative frequency $(\%)$} \\
\hline Rhizophora apiculata & 45.45 & 66.67 & 40.00 & 33.33 & 57.17 & 20.00 & 87.71 & 88.89 \\
\hline Rhizphora lamarchii & 13.64 & - & - & 16.67 & - & 30.00 & - & - \\
\hline Rhizophora mucronata & 4.55 & - & 30.00 & 16.67 & 28.57 & 20.00 & - & - \\
\hline Bruguiera gymnorrhiza & - & - & - & - & 14.29 & 10.00 & - & - \\
\hline Bruguiera cylindrica & - & - & - & - & - & 10.00 & - & - \\
\hline Avicennia marina & 27.27 & - & $\cdot$ & - & - & - & - & - \\
\hline Sonneratia alba & 9.09 & 33.33 & 30.00 & - & - & - & 1429 & 11.11 \\
\hline Ceriops tagal & - & - & - & 33.33 & - & 10.00 & - & - \\
\hline \multicolumn{9}{|c|}{ Relative dominance (\%) } \\
\hline Rhizophora apiculata & 49.14 & 85.33 & 41.50 & 47.62 & 44.26 & 17.42 & 96.86 & 65.98 \\
\hline Rhizphora lamarchii & 11.53 & - & - & 14.00 & - & 26.06 & - & - \\
\hline Rhizophora mucronata & 4.90 & - & 13.67 & 4.32 & 47.09 & 28.96 & - & $\cdot$ \\
\hline Bruguiera gymnorrhiza & - & - & - & - & 8.65 & 9.82 & - & - \\
\hline Bruguiera cylindrica & - & - & - & - & - & 12.44 & - & - \\
\hline Avicennia marina & 32.28 & - & - & - & - & - & - & - \\
\hline Sonneratia alba & 2.15 & 14.62 & 44.83 & - & - & - & 3.14 & 34.02 \\
\hline Ceriops tagal & - & - & - & 34.05 & - & 5.29 & - & - \\
\hline
\end{tabular}

apiculata and Sonneratia alba showed the value of high frequency. The higher the frequency of a species, the species has the ability to adapt to the habitat change. According to Soerianegara and Indrawan (1988), a species with high frequency give the indication that the species has the ability to compete. The frequency level also relate to the species distribution in a habitat. Yuniarto et al. (2005) stated that the species which has random distribution has the high value of frequency compared to that of clump distribution and the species with the uniform distribution has the highest value of frequency; therefore the species will have the even distribution in the habitat occupied (Table 3 and 4).

Rhizophora apiculata and Sonneratia alba are the pioneer species at the covered coastal zone, have the ability to occupy and grow at many kinds of intertidal habitats. Rhizophora apiculata and Sonneratia alba are the commonest species found at all coastal zones of Indonesia.

The same for the density and frequency values, Rhizophora apiculata and Sonneratia alba also showed the high relative domination (Table 3 and 4). The domination value of this vegetation showed the level of domination of growth by a species on the community type. If in a community has occurred a domination, it shows that the surrounding ecosystem has undergone a disturbance. A dynamic change in an ecosystem toward stability does not allow a domination. A stable ecosystem is an ecosystem consisting of many kinds of species with even individual distribution.

\section{REFERENCES}

Bosire, J.O, F. Dahdouh-Guebas, J.G Kairo and N. Koedam. 2003. Colonization of non-planted mangrove species into restored mangrove stands in Gazi Bay, Kenya. Aquatic Botany 76: 267-279.

Bosire, J.O., F. Dahdouh-Guebas, J.G. Kairo, J. Kazungu, F. Dehairs and N. Koedam. 2005. Litter degradation and $\mathrm{CN}$ dynamics in reforested mangrove plantation at Gazi Bay, Kenya. Biological Conservation 126: 287-295.

Chapman, V.J. 1976. Mangrove vegetation. J. Cramer, Valduz. $447 \mathrm{pp}$.

Cox, G.W. 1967. Laboratory manual of General Ecology. M.W.G. Brown, Company.

Dutriuex, E. 1991. Study of the ecological functioning of the Mahakam Delta (East Kalimantan, Indonesia). Est. Coast. ShelfSci., 32: 415-420.

English, S., C. Wilkinson and V. Baker. 1994. Survey manual for tropical marine resources. Published on behalf of the ASEAN-Australia Marine Science. Townswile. pp.367. 
Hamilton, L.S. and S.C. Snedaker. 1984. Handbook mangrove area management. United Nations Environment Program and East-West Center, Environment and Policy Institute, Honolulu, Hawaii. pp. 123.

Kitamura, S., C. Anwar, A. Chaniago and S. Baba. 1997. Handbook of mangroves in Indonesia. Printed by Saritaksu, Denpasar, Bali Indonesia. 119 p.

Mac Nae, W. 1968. A general account pf the fauna and flora of mangrove swamp and forest in the IndoWest Pasific Region. Adv. Mar. Biol. 6: 354-377.

Noor, Y.R., M. Khazali dan I.N.N. Suryadipura. 1999. Panduan mangrove di Indonesia. PKA/WI-IP, Bogor. 220 hal.

Notohadipoero, A.R.S. dan S.A. Siradz. 1978. Pemilihan pemanfaatan ekosistem hutan mangrove di pantai Utara Jawa. Proseding Seminar Ekosistem Hutan Mangrove. MAB-LIPI. 180-189.

Pramudji. 2000. The effort of mangrove forest management viewed from the environment protection aspect. OSEANA XVV, 2:1-8.

Pramudji dan Hermanto. 1987. Kerusakan dan langkah langkah penyelamatan hutan mangrove di wilayah Kabupaten Lombok Barat, Nusa Tenggara Barat. Perairan Maluku dan Sekitarnya. BPPSDL, P3OLIPI, Ambon 89-92.

Primavera, J.H., R.B. Sabada, M.J.H.I. Lebata and J.P. Altamirano. 2004. Handbook of mangroves in the Philippines-Panay. Published by Aquaculture Department, Southeast Asian Fisheries Development Centre. Tigbauan, Oilo, Philippines. $106 \mathrm{p}$.
Snedaker, S.C. and C.D. Getter. 1985. Coastal resources management guidelines. Research Planning Institute. Inc. 925 Gervais Street, Columbia, SC. USA 29201.pp. 205.

Snedaker, S.L. and J. G. Snedaker. 1984. The mangrove ecosystem: Research method. Published by the United National Educational, Scientific and Cultural Organisation. Bungay, United Kingdom. 251 pp.

Soerianegara, I. 1987. Masalah penentuan jalur hijau hutan mangrove. Dalam: Pros. Sem. III Ekos. Mangr. MAB-LIPI. (S. Soemodihardjo, $d k k$. Eds.): $39-47$.

Soerianegara, I. and Indrawan. 1988. Ekologi hutan Indoneia. Laboratorium Ekologi Kehutanan, Fakultas Kehutanan, Institut Pertanian Bogor (IPB), Bogor.

Soemodihardjo, S., P. Wiroatmodjo, A. Abdullah, I.G.M Tantra and A. Sugiarto. 1992. Condition, socioeconomic values and environmental significance of mangrove areas in Indonesia. National Committee on Mangrove and Coastal Ecosystem, Jakarta $58 \mathrm{p}$.

Steenis, C.G.G.J. 1978. Flora. Pradnya Paramita, Jakarta.

Syukur. 1984. Penyelamatan mangrove di Kalimantan Barat. Prosiding Seminar II Ekosistem Hutan Mangrove. MAB-LIPI. 87-89.

Tomlinson, P.B. 1986. The botany of mangrove. Cambridge University Press, Cambridge, UK. 419 hal.

Yuniarto, I., D. Hadiansyah, A. Rahmawati and L. Hakim 2005. Komposisi floristik dan analisis vegetasi hutan mangrove di desa Citalahab, Taman Nasional Gunung Halimun, Sukabumi, Jawa Barat. Laporan penelitian, Jakarta. 